\title{
NARRANDO E REFLETINDO: NOTAS SOBRE O PROJETO PET/PEDAGOGIA/RELAÇÕES RACIAIS E EDUCAÇÃO DA UNIVERSIDADE FEDERAL DO AMAPÁ
}

\author{
NARRATING AND REFLECTING: NOTES ON THE PET \\ / PEDAGOGY / RACIAL RELATIONS AND EDUCATION \\ PROJECT AT THE FEDERAL UNIVERSITY OF AMAPÁ
}

\author{
Elivaldo Serrão Custódio1 \\ [https://orcid.org/0000-0002-2947-5347] \\ Eugénia da Luz Silva Foster ${ }^{2}$ \\ [https://orcid.org/0000-0002-0807-078] \\ DOI: 10.30612/raido.v15i37.13603
}

RESUMO:O presente artigo tem como objetivo trazer reflexóes, notas de memórias e experiências sobre o processo de inclusăo da temática racial no curso de Pedagogia da Universidade Federal do Amapá (UNIFAP). Trata-se de um estudo qualitativo reflexivo a partir dos estudos de Melucci (2005), Minayo (2008), dentre outros. Os resultados apontam que as atividades relativas às diversas fases do projeto contribuíram para que a UNIFAP ampliasse seu foco de atividades, com a inclusăo de forma mais geral das discussóes sobre a temática das relaçōes raciais. Evidentemente, vem acontecendo, através da instituiçâo de políticas afirmativas na graduaçâo e na pós-graduaçăo, todas instituídas por lei, mas que careciam de sustentaçăo teórica e de uma preparaçăo mais ampla da comunidade universitária para sua efetiva implementaçăo. O projeto foi uma oportunidade ímpar na sistematizaçấo de estudos sobre o racismo no mundo e no Brasil, ao mesmo tempo que estimulou os acadêmicos bolsistas a mergulharem nas suas próprias memórias, percebendo como elas traduzem as teorias racistas dominantes, as sutilezas de um racismo disfarçado e as formas através das quais se foi aprendendo a ser racista, nas entrelinhas dos discursos, das atitudes e das situaçóes vividas, ouvidas e relatadas.

Palavras-chave: Educaçăo; Pet/Pedagogia; Relaçôes raciais; Memórias e experiências; UNIFAP.

ABSTRACT: This article aims to bring reflections, memory notes and experiences about the process of inclusion of the racial theme in the Pedagogy course at the Federal

1 Doutor em Teologia pela Faculdades EST, em Săo Leopoldo/RS com pós-doutorado em Educaçăo pela Universidade Federal do Amapá (UNIFAP). Atualmente é professor no Mestrado em Educaçăo (PPGED/ UNIFAP) e professor coorientador no Doutorado em Educaçăo da Amazônia (EDUCANORTE). Vice-líder do Grupo de Pesquisa Educaçâo, Interculturalidade e Relaçóes Étnico-Raciais (UNIFAP/CNPq). E-mail: elivaldo.pa@hotmail.com

2 Doutora em Educaçâo pela Universidade Federal de Fluminense (UFF), com pós-doutorado em Educaçăo pela Universidade Estadual do Rio de Janeiro (UERJ). Professora Associada da Universidade Federal do Amapá (UNIFAP). Atual no Mestrado em Educaçáo (PPGED/UNIFAP) e no Doutorado em Educaçáo da Amazônia (EDUCANORTE). Líder do Grupo de Pesquisa Educaçāo, Interculturalidade e Relaçôes ÉtnicoRaciais (UNIFAP/CNPq).E-mail: daluzeugenia6@gmail.com 
University of Amapá (UNIFAP). This is a qualitative reflective study based on studies by Melucci (2005), Minayo (2008), among others. The results show that the activities related to the different phases of the project contributed to UNIFAP's broadening its focus of activities, with the inclusion, more generally, of discussions on the theme of racial relations. Evidently, it has been happening, through the institution of affirmative policies in undergraduate and graduate courses, all of which were instituted by law, but which lacked theoretical support and a broader preparation by the university community for their effective implementation. The project was a unique opportunity in the systematization of studies on racism in the world and in Brazil, at the same time that it encouraged scholarship holders to delve into their own memories, realizing how they translate the dominant racist theories, the subtleties of a disguised racism and the ways in which one learned to be racist, between the lines of speeches, attitudes and situations experienced, heard and reported.

Keywords: Education; Pet / Pedagogy; Race relations; Memories and experiences; UNIFAP.

\section{PARA INÍCIO DE CONVERSA}

O narrador conta o que ele extrai da experiência - sua própria ou aquela contada por outros. E, de volta, ele a torna experiência daqueles que ouvem a história.

Walter Benjamin

Abrimos nossas reflexôes com a narraçâo de duas situaçôes de sala de aula. Uma ocorrida em uma turma do primeiro ano do ensino fundamental e outra vivenciada por um/uma dos/as autores/as em reuniăo pedagógica na escola.

\section{Situação 1 - relato de uma professora:}

Uma criança se nega a dar as mâos ao colega, em uma atividade em que era necessário que todos se dessem as mâos, em círculo. Ante a inesperada reaçâo de recusa, a professora decide forçar a situaçâo e obrigar o aluno a dar as máos ao colega, que continua resistindo. Indagada pela professora, sobre as razóes da recusa, a criança já bastante constrangida apresenta a seguinte justificativa:

"Nâo quero, ele é preto!"

Conta a professora que, perplexa diante da situaçâo, para ela inusitada na trajetória de tantos anos de magistério e oscilando entre indecisa e insegura sobre a melhor atitude a tomar resolve:

"Ah é? Entāo agora você vai abraçar e beijar seu colega, senâo vai para a diretoria". O aluno desata a chorar e a professora resolve pedir ajuda à Coordenaçâo Pedagógica.

\section{Situação 2 - vivenciada por um/uma dos/as autores/as em reunião pedagógica:}

Ao relatar a situaçâo de sua turma, em reuniâo de final de bimestre, uma professora de terceira série, em escola bem conceituada do estado do Amapá, faz o seguinte comentário: 
“Está aí, Pedro é pretinho, mas esse menino até que nâo me dá trabalho. Às vezes é atentado, mas aprende direitinho".

Interpelada sobre o caráter racista do comentário, a professora deu a seguinte justificativa e, como sempre, jogou a responsabilidade pelo "deslize" à pessoa que a interpelou.

- "Nada disso! Vocês adoram ver chifre em cabeça de galinha. Eu nâo sou racista e nâo quis dizer nada disso. Tudo vocês tomam como racismo. Isso já é complexo de inferioridade!".

Infelizmente, nâo foi possível avançar na discussâo porque a professora se fechou num mutismo carrancudo e nâo quis mais tratar do assunto.

Essas duas situaçóes acima relatadas entram aqui como mote para introduzirmos narrativas de memórias e experiências sobre o processo de inclusăo da temática racial no curso de Pedagogia da Universidade Federal do Amapá (UNIFAP) a partir da tutoria de um projeto financiado pelo Ministério da Educaçáo (MEC) denominado Pet/ Pedagogia/Relaçóes Raciais e Educaçāo no período de 2011 a 2019. Narrativas que săo complementadas por uma discussáo teórica sobre a importância da memória e das narraçōes, sobre a crítica e a ênfase dada a racionalidade na educaçáo escolar, bem como a respeito da necessidade de se pensar seriamente sobre a importância da inclusăo da temática racial, tanto na escola, como nos cursos de formaçăo de professores. Trata-se de um estudo qualitativo reflexivo a partir de Melucci (2005), Minayo (2008), dentre outros.

A atitude das duas professoras revela um despreparo de muitos profissionais, no que diz respeito ao tratamento a essa questăo, ainda muito presente nas nossas escolas; fato que pode ser lido nas entrelinhas das falas de tantos entrevistados, ao longo das nossas incursōes pelas escolas do estado do Amapá.

Elas nos instigam a algumas reflexôes sobre a memória racista que ainda prevalece na escola e que vimos tentando fraturar, ao longo dos anos, em parceria com colegas de trabalho, com nossos mestrandos e hoje doutorandos e doutores, com quem temos tido o privilégio de trabalhar e desenvolver projetos/açôes voltados para a educaçăo das relaçôes étnico-raciais. $O$ foco das nossas análises tem sido as situaçóes cotidianas de racismo em suas diversas formas e meios por onde se manifesta, como também os movimentos que buscam afirmar uma positividade do ser negro e fazer valer na prática a implementaçăo da Lei n 10.639/2003 e da Lei n 11.645/2008.

No nosso entendimento, e a partir das nossas experiências de longa data ${ }^{3}$ no campo da educaçâo, no curso de Pedagogia e nos Programas de Pós-Graduaçấo, temos alcançado alguns avanços nesse domínio, evidenciados por uma perceptível mudança no tratamento dado à questăo racial na escola, até mesmo por força da lei, ainda que saibamos que uma canetada náo é suficiente para promover as mudanças desejadas, particularmente em um tema complexo e controverso como a questăo racial no Brasil.

3 Mais precisamente, uma experiência de vinte anos em que vimos nos debruçando sobre o tema das relaçôes raciais e que teve início com a aprovaçăo de um/uma dos/das autores/as do texto no curso de Doutorado em Educaçâo na Universidade Federal de Fluminense (UFF) no ano de 2000, sob orientaçâo da professora Dra. Célia Frazăo Linhares. 
Acreditamos que para impulsionar/oportunizar mudanças efetivas, para além do conhecimento teórico do estudo, da busca de informaçôes sobre a constituiçáo histórica, social, econômica, as disputas de poder, o conhecimento das desigualdades sociais e o recorte racial presente em vários domínios, tudo isso precisa ser acompanhado de ressignificaçâo nas/das emoçōes dos professores. Consideramos que a articulaçăo da razâo com a emoçăo nessa questăo pode induzir a ultrapassagem do conhecimento meramente racional e estimular o entendimento de que para mudar a mentalidade racista que nos constitui é necessária uma revisăo urgente das nossas emoçóes sobre o outro, o diferente.

Nessa direçâo, estamos convencidos de que nessa questăo é a racionalidade que tem conduzido nossos processos de aprendizagem sobre o mundo que nos cerca e que tem levado a muitos a negligenciar o poder que a emoçăo tem no comando de nossas açôes e na forma de pensar o mundo em nossa volta. Precisamos entender, nos processos de formaçăo e outros domínios da nossa açăo educativa, que por trás de qualquer atividade nossa estará uma emoçâo que a funda e a orienta. E que essa emoçâo pode ser de aceitaçáo e/ou de rejeiçáo do outro ou do conhecimento sobre o outro (MATURANA, 1998, p. 15).

Diante do contexto, em nossas atividades de pesquisa, de ensino e de extensáo nos orientamos pelo princípio defendido por Maturana (1998) que é preciso colocar a objetividade entre parênteses, para considerar nas análises, igualmente, o domínio das emoçóes na explicaçăo da realidade, o que implicaria em pressupor a existência năo de uma verdade absoluta, mas sim de uma pluralidade de verdades.

Por outro lado, se vislumbrarmos a íntima relaçâo entre a memória e o esquecimento, poderíamos compreender ainda melhor as narrativas que usamos como exemplos para introduzir este texto. As reaçôes das duas professoras denotam uma concepçáo de homem e de mundo típica de sociedades racistas, erigidas em cima de processos nem sempre visíveis de esvaziamento das memórias e das narrativas daqueles que a história oficial insiste em atribuir um papel de meros figurantes. Parafraseando Benjamin (1994): uma visăo de história em que o cortejo dos que triunfaram avança por sobre aqueles que tiveram sua história negada.

Benjamin (1994) ao atrelar a memória à significaçăo de experiências, nos mostra como em um mundo cada vez mais fragmentado a experiência está perdendo o seu lugar de honra na constituiçáo dos modos de viver. A memória continua atrelada à efemeridade de um presente destituído do passado que o significa e o dá sentido. Procura-se apagar os vestígios, os rastros do passado porque náo temos mais experiências narráveis para compartilhar. Dessa forma a humanidade vai ficando mais pobre devido ao culto do atual desenvolvimento da tecnologia e da disseminaçăo da informaçāo jornalística.

Escovar a história a contrapelo - um dos pontos fundamentais do pensamento de desse autor, ao acreditar que para ultrapassarmos esse culto ao efêmero precisamos constituir uma experiência com o passado, pois esse encerra histórias de lutas, sonhos e utopias nâo concretizados e que precisam ser continuados. Rememorar é nâo deixar cair no lago do esquecimento a história das lutas de nossos antepassados, seus sonhos e desejos de liberdade. É o momento de voltar a olhar para trás e identificar no passado coberto por uma névoa de falsa harmonia, um lampejo de outro futuro. 
Sabia-se exatamente o significado da experiência: ela sempre fora comunicada aos jovens. De forma concisa, com a autoridade da velhice, em provérbios; de forma prolixa, com sua loquacidade, em histórias; muitas vezes como narrativas de países longínquos, diante da lareira, contadas a pais e netos. Que foi feito de tudo isso? (BENJAMIN, 1994, p. 114).

Evidências de uma memória individual e coletiva que se apoia em narrativas de uma história da negritude que, embora fraturada na contemporaneidade, insiste em recrudescer nos interstícios das relaçōes entre o "nós e os outros" ao insistir em afastar os próprios negros da experiência da negritude. Uma experiência que poderia ser o ponto de partida para o resgate da outra memória, aquela negligenciada e relegada ao esquecimento por determinados processos de formaçăo de professores. Aqui lembramos a obra de Dávila (2006) intitulada Diploma de Brancura: o que aconteceu com os professores de cor do rio? ${ }^{4}$

Aponta que os reformadores da educaçâo viam a profissionalizaçăo como um processo meritocrático e técnico. Uma política ideológica e preconceituosa que claramente diminuía as chances a principalmente homens pobres e afrodescendentes e assentada em valores combinados de raça, classe e gênero, onde ser branco, feminino e de classe média era o valor padrăo que precisava ser implantado e atingido, mediante certas políticas educacionais.

Chauí, em 1994, na apresentaçāo da obra de Ecléa Bosi "Memória e Sociedade: Lembranças de Velhos" afirma que lembrar significa re-fazer, um processo de reflexăo, de compreensáo do agora a partir do outrora. Lembrar é compreender o presente a partir das experiências que se teve no passado. A lembrança - continua Chauí, precisa ser lapidada pelo espírito; é um trabalho sobre o tempo onde procuramos recriá-lo constituindo-o como 'nosso' tempo. Ao recordar, fica o que significa (BOSI, 1994).

Perguntamos nessa rememoraçăo: O que ficou para os nossos alunos e professores da recordaçâo de suas experiências em torno da questâo racial promovidas no âmbito das atividades do Projeto PET? Que significados essas experiências têm para eles hoje? Que reflexóes eles vêm fazendo sobre o tema? Há indícios de uma reflexâo crítica sobre o que significa para a prática educativa esse processo de revisáo de memórias? Que processos de ruptura estăo ganhando espaço na escola?

E é com base nessas indagaçôes que acreditamos na natureza instituinte do Projeto PET e outros desenvolvidos por nós no âmbito das atividades de ensino, pesquisa e extensăo, na mesma direçăo do que vimos trabalhando até agora. Experiências que, através da atuaçâo destacada dos professores têm circulado na escola procurando construir outra realidade. Se estudamos os movimentos instituintes em sua relaçâo com a questâo das relaçóes raciais e educaçăo é porque apostamos que importantes segmentos sociais desejam outra escola e por isso partilham do desafio de reinventá-la.

Os projetos instituintes em educaçăo sâo formas de anunciar reversōes na própria racionalidade e política dominante, de modo a preencher lacunas e vazios deixados

4 A autora trata nessa pesquisa dos processos históricos que levaram ao gradual branqueamento do quadro de professores do estado do Rio de Janeiro. Nessa investigaçáo procurou investigar a dinâmica de branqueamento no âmbito dos processos de profissionalizaçăo do ensino e de treinamento de professores, na história da formaçăo de professores no Rio de Janeiro. 
por uma organizaçăo do saber hierarquizado e excludente de outros saberes, de outra corporalidade e de outras memórias. Sua origem está atrelada com a vida, com a história e com as açóes coletivas e individuais que se alimentam de uma memória, para dar sentido ao que ficou suspenso no passado e que clama por uma soluçâo (LINHARES, 2000, 2002, 2006, 2010).

Constituindo-se como uma busca de alternativas para a educaçăo, mais particularmente para as instituiçôes de ensino e as de formaçăo de professores, os movimentos instituintes sâo aqueles "capazes de anunciar o novo, como ruptura de sucessivas e acumuladas opressóes" (LINHARES, 2002) e conjugam projetos múltiplos de sociedade e de educaçăo. Săo projetos que postulam processos escolares que defendem concepçóes de conhecimento em que sujeito e objeto se interpenetram e se conjuguem com a vida. Neste sentido cabe perguntar: que dimensôes săo essenciais na formaçấo de professores para que nossos cursos possam religar os saberes produzidos socialmente, na perspectiva de uma açăo pedagógica ética, plural e autônoma?

Na direçâo contrária a natureza reprodutora das reformas, continua Linhares (2000, 2002, 2006), dizendo que săo projetos construídos na busca de inventar mais do que reproduzir, compartilhando dúvidas e enigmas e diminuindo certezas e arrogâncias. Para isso, o cotidiano escolar pauta-se num projeto de sociedade onde os partidos políticos, associaçóes, sindicatos e movimentos sociais buscam instituir uma nova ordem social e escolar.

Diante desse contexto, esta reflexăo nos remete às contribuiçóes de Benjamin (1994), para o sentido das 'experiências plenas', que se traduzem por uma tessitura coletiva e pela possibilidade de abertura polifônica. A experiência instituinte se afirma como uma experiência compartilhada por um grupo, contrapondo-se ao pontual e fragmentado do sujeito isolado. É uma experiência aberta, năo se afirma como 'símbolo', com um significado unilateral, mas como ‘alegoria' por seus múltiplos sentidos e leituras. Podemos articular este conceito ao sentido de 'origem' em Benjamin (1994).

Assim, o instituinte năo se confunde com o'novo', mas é busca constante do movimento emancipador que articula passado, presente e futuro. Contrapondo-se ao modismo e a uma reproduçăo estática do passado, a experiência instituinte sinaliza a densidade da experiência humana ao recuperar o sentido de uma memória viva, pulsante onde o olhar para o passado potencializa o presente e nos ajuda na construçăo dos projetos de futuro, pois que é ancorada em uma memória que é capaz de prometer (LINHARES, 2000).

As Experiências Instituintes săo exemplos de movimentos que procuram seguir na contramáo das tendências cristalizadas na escola. Com elas, busca-se desocultar opressóes silenciadas por um projeto de sociedade e de educaçăo hegemônica, ao mesmo tempo que se apoiam numa outra lógica e numa concepçăo de conhecimento náo hierarquizado. Dessa maneira, atendemos a um requisito básico: o de que a escola náo é só um meio de reproduçâo, mas também ela se constitui num espaço de reconstituiçâo de memórias e projetos onde se conjugam existência e ciência, razăo e poesia, vida e conhecimento lógico-racional (LINHARES, 2000, 2002, 2006, 2010).

É com este espírito que buscamos aqui narrar as experiências sobre relaçôes raciais no Curso de Pedagogia da UNIFAP e o fazemos também na perspectiva de Bruner (2001) quando aponta para a narrativa como um modo de pensamento e como um veículo de produçăo de significado. Afirma esse autor que o homem usa duas formas 
para organizar seu conhecimento do mundo e estruturar sua experiência imediata: o pensamento lógico-dedutivo e o pensamento narrativo. Representamos nossas vidas na forma de narrativa, e estruturamos nossos relatos sobre o mundo, sobre nossas origens e nossas crenças de modo narrativo, embora as artes da narrativa - a ficçáo, o drama o teatro, o canto - tenham sido convencionalmente encaradas nas escolas mais como "decoraçăo".

Na esteira dessas consideraçôes iniciais nos indagamos novamente: Por que razâo esse movimento de recuperaçáo da memória em um processo narrativo de experiências compartilhadas no âmbito de um trabalho realizado no curso de Pedagogia? Para recuperar essa memória do Pet/Pedagogia/Relaçóes Raciais e Educaçâo, portanto, nos ancoramos nas contribuiçóes dos estudos sobre memória e narraçōes, memória e experiência para trazer a lume năo só as nossas memórias, mas também as memórias raciais dos alunos, de modo que no seu processo de formaçăo as usem como ferramentas para fecundar um processo de formaçâo de professores mais crítico e socialmente engajado.

Năo podemos esquecer nossa luta dentro do próprio curso de Pedagogia para introduzir estudos sobre relaçóes raciais na matriz curricular do mesmo, na altura uma temática encarada como tema de pesquisa de menor relevância cientificamente. Náo esquecemos a estranheza, as reservas com que o projeto Pet/Pedagogia/Relaçóes Raciais e Educação foi acolhido, além das tentativas de colegas professores do mesmo colegiado em esvaziar os grupos, aliciando-os para outros projetos tidos como mais importantes na formaçáo docente. A fala de um professor do curso de pedagogia é elucidativa dessa estranheza: "Está na hora de o grupo de pesquisa sobre relaçōes raciais dar lugar a outros projetos. Já tem TCC demais sobre esse tema", etc.

Portanto, dar existência a essas memórias significa, pois, entrever nas memórias escolhidas possibilidades de estudo sobre o negro na sociedade brasileira e na escola. Nâo esquecemos que tanto nós professores como os alunos narradores estamos vinculados por um imaginário comum sobre negritude, sobre o lugar do negro na sociedade brasileira, sobre a diferença, sobre o outro que fomos introjetando através do espaço escolar, da mídia, familiar, religioso, social e ficcional.

\section{A ESCOLA E A UNIVERSIDADE COMO ESPAÇOS PARCEIROS DE FORMAÇÃO: PEQUENOS RELATOS DE UMA EXPERIÊNCIA}

O projeto Pet/Pedagogia/ Conexôes de Saberes: relaçôes étnico-raciais insere-se no âmbito mais amplo do PET promovido pelo Ministério da Educaçăo (MEC) que envolve atividades de ensino, pesquisa e extensăo. A proposta de constituiçăo de um grupo PET/Pedagogia na UNIFAP foi pensada inicialmente por duas professoras do curso de Pedagogia da mesma instituiçấo que ministravam, em parceria, a disciplina Seminário de Pesquisa, com o tema Educaçăo para as Relaçôes Raciais.

A proposta foi aprovada em nível nacional no ano de 2010, com a colaboraçâo ativa de professores/as do curso de Pedagogia e de mestrandos/as sob nossa orientaçáo, em um esforço de articular a graduaçấo com a pós-graduaçăo na formaçâo dos acadêmicos/as.

O projeto em seu nascedouro previa a participaçăo de estudantes dos cursos de Pedagogia, Direito, Enfermagem, Ciências Ambientais e atribuía bolsas de estudos a doze bolsistas de graduaçăo a cada dois anos. No entanto, por dificuldades outras como 
espaço adequado para desenvolver as atividades, bem como outras questóes logísticas, decidimos nos limitar aos cursos de Pedagogia e Enfermagem, inicialmente, para depois limitar mais ainda para apenas o curso de Pedagogia.

Em termos institucionais o projeto PET configura-se como projeto de Extensăo e tem como objetivo a ampliaçăo e o fortalecimento dos vínculos entre a Universidade e a Escola Básica, atuando na formaçâo inicial e continuada de professores. Quase todos os colaboradores, encontravam-se, no período, na condiçâo de alunos inscritos nos Programas de Pós-graduaçâo aos quais a professora tutora estava vinculada.

O projeto antes era intitulado: Questâo étnico-racial em contextos educativos formais e nâo-formais localizados em comunidade do campo e quilombolas do Amapá. Tinha como objetivo promover a articular açôes e reflexôes dentro da temática das relaçóes raciais e educaçâo, em diálogo com as experiências escolares e năo escolares. Encontrava-se articulado à Linha de Pesquisa cadastrada no CNPq sob o título de "Educaçāo, Relaçōes Étnico-Raciais e Interculturais".

O projeto apresentava as seguintes características: 1) Um caráter interdisciplinar que busca favorecer uma formaçăo acadêmica condizente com o estágio atual do desenvolvimento do conhecimento dos cursos envolvidos (Pedagogia, História, Ciências Sociais, Ambientais, Direito e Enfermagem) através da articulaçâo ensino, pesquisa e extensâo; 2) Caráter integrador pela articulaçăo entre universidade e comunidades; 3) Visava promover a inclusăo social e educacional das populaçóes tradicionais do campo e quilombolas através de atividades realizadas em campo pelos "petianos"; 3) Tinha como alguns dos objetivos promover a qualificaçâo dos estudantes de origem popular; introduzir o acadêmico no âmbito da Metodologia Científica e na produçáo de conhecimento nas diversas áreas temáticas e na questăo racial.

Como justificativa para a sua implementaçăo elencamos alguns aspectos importantes: 1) Um índice significativo de situaçôes de discriminaçăo racial apontados por estudos e pesquisas que sugeriram a percepçăo de uma distância entre um discurso de inclusáo cada vez mais sofisticado no campo educacional e a vivência cotidiana de crianças e jovens negros e negras. Realidade que naquele momento sugeria uma maior atençăo aos mecanismos que promoviam o silenciamento como uma das formas aparentemente eficazes para escamotear as relaçóes desiguais dentro da escola e fora dela; 2) Desconhecimento por parte dos cursos de formaçăo de professores sobre os processos de discriminaçấo racial e, consequentemente, pouco ou quase nula capacidade técnica para os encaminhamentos necessários na escola. Muitos professores preferiam desvalorizar, desconsiderar a importância da questăo racial como elemento imprescindível no currículo das escolas e na universidade e na construçăo de uma educaçăo plural e democrática; 3) Necessidade de destacar o papel articulador da universidade na aproximaçáo entre a teoria com a prática nesta e outras questóes candentes na nossa sociedade, na busca de respostas aos desafios com os quais lidamos cotidianamente. O processo de pesquisa aqui comparece como um espaço importante para promover essa articulaçâo.

Naquele momento foi avaliada a necessidade de dar continuidade a um projeto de pesquisa que vinha sendo executado por uma das professoras, desde agosto de $2006^{5}$,

5 Nos referimos ao projeto intitulado: Questăo Racial na Escola: Repensando a Formaçăo de Professores: 2006-2008. 
onde passamos a acrescentar à proposta inicial, além da ampliaçăo do universo escolar contemplado no projeto anterior, com a inclusăo de escolas localizadas em comunidades quilombolas, a partir náo só da realizaçáo de atividades de pesquisa com professores, alunos, coordenadores pedagógicos, diretores, inspetores e serviços de apoio, mas também o desenvolvimento de atividades de colaboraçăo com a escola. A intençăo era a de contribuir com elementos teóricos e metodológicos com a prática dos professores, através da realizaçâo de discussôes, debates, cursos de atualizaçăo e aperfeiçoamento, bem como a constante ampliaçăo teórico-metodológica, nessa questăo.

Assim sendo, propomos na época, apresentar mais uma contribuiçăo ao debate sobre a temática racial na educaçăo, no estado do Amapá, procurando aprofundar a compreensáo dos desafios enfrentados pelos sujeitos que se no seu cotidiano lidam com processos de formaçáo de outros sujeitos e com isso buscam promover uma real democratizaçăo do ensino no estado e no país.

Como princípio básico norteador das nossas açôes de ensino, pesquisa e extensâo dentro e fora da universidade, o projeto ancorou-se no princípio político e epistemológico que até hoje nos instiga a ampliar nosso olhar para além do visível à priori e considerar aqueles elementos tido como negligenciáveis por serem menores e pouco reconhecidos por uma determinada ciência. Ou seja, considerávamos e até hoje consideramos importante o reconhecimento de outras dimensóes da prática educativa, para além do domínio racional, buscando, no que diz respeito à temática racial, ressaltar as sutilezas por onde o racismo vai se metamorfoseando, sem desconsiderar os movimentos que vêm seguindo na contramáo das práticas racistas no contexto educativo.

Os esforços demandados nas pesquisas de doutorado nos revelaram a necessidade de aprofundar esse debate no campo da formaçâo docente, acrescentando a ele outros elementos como uma avaliaçăo dos avanços e as dificuldades dos professores que atuam na escola básica, capazes de indicar o direcionamento que vem sendo dado a essa questăo nas escolas amapaenses, considerando a implementaçăo da Lei n 10.639/2003 que institui a obrigatoriedade do ensino de História e Cultura afro-brasileira, bem como de História da África e dos africanos nos estabelecimentos de ensino públicos e privados no Brasil. Pensamos também que as escolas podem ser espaço de compartilhamento de observaçôes, problematizaçôes, teorizaçôes e debates que funcionam como "comunidades científicas ampliadas", que tendem a se ampliar, transbordando acuidade de questionamento em todo o cotidiano escolar.

No que diz respeito à articulaçăo como o Projeto Pedagógico do curso, a proposta do PET considerava ainda os seguintes aspectos: 1) A possibilidade de o PET contribuir com a elevaçấo qualitativa do Curso de Pedagogia da UNIFAP por meio do fomento e realizaçấo de atividades de ensino, pesquisa e extensâo; 2) A necessidade de implantaçâo de programas que favoreçam, na Amazônia, o desenvolvimento de pesquisas e atividades de extensăo em curto e médio prazo; 3) A correlaçấo dos objetivos do programa PET com as demandas acadêmicas hoje existentes na UNIFAP; 4) A capacidade do PET permitir a criaçăo de uma estrutura de trabalho que facilite o desenvolvimento de projetos individuais e coletivos, favorecendo a investigaçâo científica, a inclusăo social e o intercâmbio entre universidade e os espaços educativos formais e nâo formais; 5) A necessidade de novos vínculos institucionais que permitam ao acadêmico contato com sua área de trabalho e o desenvolvimento de suas habilidades em sua totalidade. 
O projeto que ensejou esse relato/reflexáo contemplou, ao longo dos anos, uma série de atividades dentro do espaço da universidade e fora dele. Isso incluiu atividades de embasamento teórico sobre o tema das relaçóes raciais e suas relaçóes com a educaçấo, atividades que envolviam a participaçấo em eventos culturais sobre a temática negra no Estado do Amapá; palestras e outras intervençôes em escolas e em outros foruns que discutem a questâo racial na educaçấo escolar; participaâo em projetos promovidos por agentes culturais; levantamento através de entrevistas em escolas, associaçóes culturais, incluindo entrevistas com expoentes da cultura negra do estado, bem como as experiências escolares e năo escolares relacionadas ao tema em estudo.

No âmbito das práticas educacionais que visam a construçấo de uma escola mais inclusiva e năo racista e que se apoiam em movimentaçóes ${ }^{6}$ fora da escola buscamos contemplar tanto as açóes de inclusâo da cultura negra desenvolvidas por escolas amapaenses, em seu currículo oficial como os projetos educativos em execuçâo fora do espaço escolar, mas nâo menos importantes na sua potência para a transformaçâo, mas que têm a finalidade educativa na promoçâo da inclusâo e visibilidade da cultura negra na sociedade. Tendo em vista do projeto supracitado, foi prevista a realizaçấo de entrevistas com vários profissionais e pesquisadores que trabalham com a temática racial, em campos diferenciados dentro da educaçăo e preocupados com aspectos diversos dessa problemática é que consideramos a participaçăo do professor Carlos Augusto Gomes de Macapá-AP7 .

Em termos metodológicos nos orientamos na elaboraçăo e realizaçăo do projeto PET pela seguinte opçâo teórico-metodológica: método crítico-dialético, por considerarmos que o conhecimento náo pode ser entendido isoladamente em relaçáo à prática política dos seres humanos; Abordagem qualitativa, pois segundo Chizotti (2000) é a que permite a aproximaçăo, de maneira detalhada, profunda e analítica à problemática de pesquisa.

Permite, portanto, analisar as falas e açōes dos sujeitos envolvidos, suas crenças, modos de atuaçâo, práticas e processos educativos cotidianos. Esse autor considera que a pesquisa qualitativa parte do fundamento de que há uma relaçâo dinâmica entre o mundo real estudado e o sujeito, em uma relaçấo de interdependência entre sujeito e objeto.

Nessa concepçâo, o projeto pautou-se pelo princípio de nâo neutralidade do pesquisador. Optamos também pela pesquisa colaborativa, por se apresentar como um projeto que envolve etapas distintas, mas que se entrecruzam: embasamento teórico-metodológico na questăo da Educaçấo e Relaçôes Raciais e aspectos metodológicos; Definiçâo de estratégias didático-metodológicas que permitam a colaboraçâo nas escolas, com vistas a contribuir para a formaçấo continuada dos professores da

6 Por movimentaçóes estamos entendendo, inspirados por Heckert (2004), aqueles processos anônimos, năo politicamente organizados, batalhas cotidianas que engendram outros possíveis e suas ressonâncias que procuram criar outros modos de agir e que visam provocar fraturas no instituído, porém ainda năo se configuram como movimentos plenamente reconhecidos e instituídos.

7 Conhecido popularmente como "Carlităo" é um dos fundadores da Banda Placa de Macapá-AP criada em 09 de março de 1983. Muito atuante no campo das atividades culturais, pois vem promovendo a recolha de traços da memória da presença negra no Amapá. 
Educaçăo Básica. É pertinente destacar que o desenvolvimento do projeto envolveu várias açōes, além de atividades de embasamento teórico e de participaçâo em projetos extra universidade.

O trabalho iniciou com um levantamento da percepçáo dos bolsistas sobre a questáo racial. Ao término de cada período fazíamos esse mesmo levantamento, a fim de perceber o que havia mudado na percepçâo do estudante de Pedagogia sobre a questâo racial, a fim de mudar as estratégias, incentivar mais as leituras e discussóes, bem como motivar para um maior envolvimento com o tema. Estas atividades foram constantes durante todo o período. Ao mesmo tempo buscou-se realizar uma preparaçâo teórico-metodológica dos alunos no tema das relaçôes étnico-raciais e educaçăo, bem como do referencial teórico de apoio e englobou:

Revisâo bibliográfica sobre a temática das relaçôes raciais no Brasil e sua relaçáo com a educaçấo quilombola, com o objetivo de propiciar a construçăo de uma visâo crítica sobre a questâo racial no Brasil e seus desdobramentos na educaçăo. Essa revisăo propiciou ao estudante vinculado oportunidades de contato teórico e reflexóes a respeito da questăo racial no Brasil em seus aspectos históricos, sociológicos, antropológicos, econômicos, literários etc.

As atividades relacionadas a esta etapa constaram, em linhas gerais, em contribuir para o desenvolvimento do senso crítico, de responsabilidade política e social, bem como uma visăo crítica da sociedade e do mundo mais amplo, com vistas a buscar caminhos de intervençáo para a mudança e sensibilizaçâo.

Ao mesmo tempo, de posse do referencial teórico-epistemológico trabalhado ao longo do projeto, esperou-se que o acadêmico fosse o multiplicador junto à sua turma e às outras turmas de graduaçáo da UNIFAP. Em termos mais específicos tratou-se de abordar os seguintes temas, entre outros nâo menos importantes: conceitos de raça, racismo e preconceito racial, compreendendo a origem desses conceitos, sua relaçâo com a Biologia e como foram usados para disseminar uma ideia de diferenças raciais entre seres humanos que sobrevive até hoje, em vários domínios da vida e do conhecimento. A ideia de raça é um dos fundamentos do racismo no Brasil e da desigualdade racial entre brancos e negros. O racismo no Brasil enquanto construçăo histórica e teórica, avalizado por uma pseudociência. Movimentos instituintes ${ }^{8}$ que buscam a valorizaçấo das diferenças em seus vários aspectos e suas conexôes com as manifestaçôes culturais e sociais do estado do Amapá.

Enquanto fundamento para uma mudança de conceitos, de atitudes e de visâo de mundo por parte dos acadêmicos, as atividades concernentes à etapa do embasamento teórico foram permanentemente avaliadas, tendo como critérios: participaçăo e assiduidade em todas as atividades realizadas; evidências de mudança de postura do acadêmico sobre a temática em foco; leituras e apreensăo dos conceitos básicos, bem como sua demonstraçâo nas discussôes em grupo; elaboraçăo de resenhas críticas de textos básicos discutidos e outras atividades como elaboraçāo de análises críticas de documentários e

8 Os movimentos instituintes năo se dispōem como objetos prontos a serem descobertos por investigadores geniais e certeiros; somos todas/os fabricantes nesses e desses processos instituintes/instituídos, pois eles dependem do modo com que os percebemos, os desejamos, intensificando condiçóes e possibilidades de seus caminhos de construçấo, que nâo desprezam o aproveitamento de frestas (LINHARES, 2010, p. 801-818). 
filmes exibidos. Capacidade de iniciativa do "petiano" em propor atividades, em usar a criatividade, bem como demonstraçâo de espírito colaborador com colegas.

A seguir, destacamos alguns temas desenvolvidos durante a execuçăo do projeto: 1) Conceitos básicos: raça, racismo, preconceito, discriminaçăo racial; relaçôes étnico-raciais no Brasil; as teorias raciais, mestiçagem e branqueamento na construçâo da identidade racial, questóes relevantes, o mito da democracia racial; movimentos instituintes na escola; Leitura e discussăo de texto sobre o "tornar-se negro"; Discussôes atuais sobre o tema - críticas ao mito da democracia racial; a Lei $n^{\circ}$ 10.639/2003; relaçóes raciais e educaçâo: sutilezas e movimentos instituintes - questóes relevantes levantadas por estudos e pesquisas já realizados; Algumas questōes atuais sobre currículo e educaçăo quilombola (ALVES, 2005; BENJAMIN, 1994, BRASIL, 2003; CANEN, 2000; CAVALLEIRO, 2012; FANON, 2008; FOSTER, 2005; GOMES, 1995, 2005, 2012, LINHARES, 2000, 2002, 2006, 2010; MUNANGA, 2008; SOUZA, 1983; TRIVIN̂OS, 2008; LÜDKE, ANDRÉ, 2013).

Vale ressaltar que este projeto gerou ainda alguns relatórios individuais com depoimentos dos acadêmicos e acadêmicas que fizeram parte desse projeto. Perguntados sobre a importância de se estudar o tema das relaçôes raciais e seus desdobramentos no campo da educaçăo e formaçâo de professores, eis algumas respostas:

Considero que é de extrema importância o tema, para realizar o meu trabalho como futuro professor, pois para falar de racismo é preciso estudar, se aprofundar em conhecimentos que envolvam a compreensăo de direitos, de lutas, para derrubar tabus e achismos, a fim de construir uma sociedade justa, respeitável e entender que a religiosidade, cultura e educaçăo năo têm nada a ver com cor da pele, vestimentas ou posiçăo social. (ACADÊMICO/A DO CURSO DE PEDAGOGIA E BOLSISTA DO PET/ PEDAGOGIA/RELAÇŌES RACIAIS).

Estudar o tema voltado às questōes étnico-raciais tem muita relevância, pois o pedagogo precisa ser um mediador de conflitos quando se deparar com o preconceito em seu ambiente de trabalho (ACADÊMICO/A DO CURSO DE PEDAGOGIA E BOLSISTA DO PET/PEDAGOGIA/RELAÇÔES RACIAIS).

As açóes racistas acontecem todos os dias e em todos os momentos na vida cotidiana. Por isso, o pedagogo precisa ter noçóes de como resolver as situaçôes com que vai se deparar no seu trabalho (ACADÊMICO/A DO CURSO DE PEDAGOGIA E BOLSISTA DO PET/PEDAGOGIA/RELAÇŌES RACIAIS).

A formaçăo em pedagogia envolve diretamente entender as relaçóes escolares. ambiente onde há múltiplas personalidades, inúmeros conflitos originados a partir de uma abordagem secular eurocêntrica, entre os quais encontram-se as relaçôes énico-raciais. $O$ aprofundamento no tema ampliará a habilidade de contornar conflitos e a busca de construçâo de relaçôes de solidariedade, de respeito e tolerância dentro do ambiente escolar, principal palco de lutas (ACADÊMICO/A DO CURSO DE PEDAGOGIA E BOLSISTA DO PET/PEDAGOGIA/RELAÇŌES RACIAIS).

O Estudo das relaçôes raciais no curso de Pedagogia é de suma importância na nossa formaçấo, tendo em vista que o pedagogo, pois como um profissional da educaçăo 
irá se deparar com situaçôes diversas de preconceito, racismo, exclusâo e outros. é imprescindível que o educador esteja preparado para trabalhar e lidar com esses temas no ambiente escolar, a fim de contribuir para a formaçăo de cidadáos mais conscientes (ACADÊMICO/A DO CURSO DE PEDAGOGIA E BOLSISTA DO PET/ PEDAGOGIA/RELAÇŌES RACIAIS).

Houve ainda várias participaçôes em eventos culturais e educacionais em escolas no estado do Amapá, bem como em comunidades quilombolas, entrevistas com líderes comunitários, bem como coleta de narrativas de pessoas idosas que trouxeram uma bagagem histórica sobre essas comunidades.

Os bolsistas também foram sempre convocados/instigados a participar de bancas de apresentaçăo de Trabalho de Conclusấo de Curso (TCC), bancas de qualificaçấo e defesa de dissertaçấo, produçáo científica, dentre outros. É pertinente destacar que além das atividades realizadas mediante a leitura e discussâo dos TCC e as dissertaçóes de mestrado orientadas por nós sobre a temática das relaçôes raciais, buscamos incentivar os bolsistas do PET a participarem de aulas de Seminário de Pesquisa I, II, III, IV, bem como nos encontros do grupo de pesquisa para discussăo da temática racial nas suas interfaces com a educaçăo, tanto na UNIFAP como em outras localidades. Nossos alunos têm, portanto, no chăo da escola e outros espaços, com suas problemáticas, o alimento para suas pesquisas e o espaço onde possam articular a teoria com a prática.

Ainda no âmbito do PET e do grupo de pesquisa fizemos várias incursōes por escolas localizadas em comunidades quilombolas do estado do Amapá, de modo a compreender os processos de inclusáo da cultura negra nos currículos escolares, seus desafios e perspectivas. Ao mesmo tempo realizamos entrevistas dentre as quais destacamos a entrevista com a liderança da Banda Placa Produçóes Culturais ${ }^{9}$. Igualmente acompanhamos as atividades culturais realizadas pelo Grupo Raizes do Bolăo ${ }^{10}$, assim como o Ponto de Cultura da cidade de Mazagăo Velho-AP. Tudo isso a alimentar nossas discussóes e análises, além de fornecerem material para os artigos científicos e trabalhos para apresentaçăo em congressos científicos da área. Atividades outras como: Palestras e outras intervençóes em escolas e em outros foruns que discutem a questâo racial na educaçấo escolar fizeram parte do rol de atividades do nosso grupo, em conjunto com o Núcleo de Relaçōes Raciais do Governo do Estado do Amapá (NEER).

\section{CONSIDERAÇÕES FINAIS}

O projeto PET relaçôes raciais foi uma oportunidade ímpar na sistematizaçăo de estudos sobre o racismo no mundo e no Brasil, de revisitar conceitos como os de racismo, discriminaçấo racial e preconceito racial, ao mesmo tempo que estimulou os acadêmicos bolsistas a mergulharem nas suas próprias memórias raciais, percebendo

9 A Banda Placa além de produzi músicas voltada para a cultura amapaense realiza projetos culturais, sociais e educacionais, fomentando o legado da produçăo histórica e cultural do Amapá.

10 O grupo Raízes do Bolâo vive no quilombo do Curiaú, área rural da cidade de Macapá-AP, onde mantém a tradiçâo de cantar os ladrôes (cânticos) que falam de situaçôes diversas do cotidiano e de temas religiosos da cultura negra amapaense. 
como elas traduzem as teorias racistas dominantes, as sutilezas de um racismo disfarçado e as formas através das quais se foi aprendendo a ser racista, nas entrelinhas dos discursos, das atitudes e das situaçôes vividas, ouvidas e relatadas.

Os momentos de reuniâo coletiva para estudos de textos, para discutir situaçóes concretas ou outros conteúdos planejados contribuíram para entender o racismo presente no Amapá e no Brasil, suas bases de sustentaçăo, as sutilezas que a realimentam na fala dos professores sobre suas experiências em família e na escola.

A etapa de preparaçăo para ida a campo compreendeu o estabelecimento do início dos contatos com as escolas, o levantamento das necessidades das mesmas, escolha dos temas, preparaçáo em termos teóricos e metodológicos nos conteúdos necessários para a atividade, elaboraçâo do projeto de colaboraçấo, em todas as suas etapas. Ao mesmo tempo, procurou-se divulgar o trabalho junto aos demais alunos da UNIFAP, mostrando sua importância na formaçấo de professores e de cidadáos.

As colaboraçôes consistiram na realizaçâo de palestras, oficinas, minicursos e outras atividades paralelas. $O$ grupo também desenvolveu também atividades nas outras turmas do curso de Pedagogia, com o objetivo de promover a divulgaçấo das atividades do Pet/Pedagogia Relaçōes Raciais e Educaçāo e chamar os outros estudantes para o envolvimento com a temática. As açóes consistiram na realizaçăo de palestras, oficinas, minicursos e outras atividades paralelas.

Avaliamos que todas as atividades relativas às diversas fases do projeto contribuíram para que a UNIFAP ${ }^{11}$ e o curso de Pedagogia ampliassem seu foco de atividades, com a inclusâo de forma mais geral das discussōes sobre a temática das relaçôes raciais, o que, evidentemente, vem acontecendo, através da instituiçăo de políticas afirmativas na graduaçấo e na pós-graduaçăo, todas instituídas por lei, mas que careciam de sustentaçăo teórica e de uma preparaçăo mais ampla da comunidade universitária para sua efetiva implementaçăo.

Através das atividades do PET percebemos que outros cursos da universidade conjugaram esforços no sentido de ampliar suas discussôes, incluindo a temática racial em seus vários desdobramentos. Importa ainda destacar que, embora tenha sido ainda um ponto frágil, alguns dos nossos estudantes se empenharam em publicar artigo sobre o tema, em revista científica da área educacional e participar de atividades de divulgaçâo do trabalho em eventos científicos locais, regionais e nacionais.

Nos encontros de avaliaçăo foi consenso entre todos que os estudos contribuíram

11 É pertinente destacar que com o fruto dessa experiência instituinte, ficou bastante perceptível o aumento significativo da procura pelo tema e o incremento da participaçăo e do interesse nâo só pelo Pet/Relaçóes Raciais e Educaçăo, como também pelo componente curricular do curso de pedagogia "Seminário de pesquisa I, II, III E IV" que trouxe a ideia como tema de pesquisa, os TCC decorrentes desse componente curricular; a disciplina também do curso de pedagogia "Educaçấo para as relaçóes étnico-raciais" e várias outras atividades dentro do curso que englobaram debates sobre a importância do tema na formaçấo de professores e, no âmbito dos programas de pós-graduaçấo em que os autores participaram e ainda participam, seja em parceria, seja individualmente e/ou em grupos, percebemos igualmente um aumento crescente da procura por uma vaga no Mestrado em Educaçăo (PPGED/ UNIFAP) e atualmente Doutorado em Educaçâo na Amazônia (EDUCANORTE) para pesquisar sobre esse assunto em eixos diversos. A exemplo desse incremento na procura por uma vaga, apenas no Mestrado em Desenvolvimento Regional da UNIFAP - processo seletivo do ano de 2015/2016 - inscreveramse mais de 250 candidatos para disputar apenas três vagas disponibilizadas para o tema "Educaçăo e Relaçôes Raciais na Amazônia". 
sobremaneira para o desenvolvimento do espírito crítico sobre a sociedade brasileira, sobre o mundo e sobre a realidade das escolas da sua regiâo, de um lado, e de outro possibilitaram a aplicaçăo dos conhecimentos adquiridos, em diálogo com professores e alunos, levando-os a uma reflexăo mais ampla.

Além disso, ainda na fala dos bolsistas ${ }^{12}$, os estudos relativos ao projeto propiciaram a eles outras ferramentas que permitiram atividades pedagógicas antirracistas, mais inclusivas e interculturais, além de desenvolver habilidades relativas à pesquisa teórica, de campo, metodologias de ensino e pesquisa, capacidade de lidar com as diferenças, valorizando-as ao invés de discriminá-las. Enfim, ampliar seu senso de cidadania. Em destaque o processo de estímulo aos demais colegas do curso e de outros cursos, alertando-os para a importância de uma reflexâo mais crítica sobre a temática das diferenças, de um modo geral, na construçâo de uma sociedade realmente democrática.

O processo de tutoria se deu sempre em todas as etapas. O tutor/a esteve presente na grande maioria dos eventos e discussōes e em todas as atividades realizadas dentro e fora da instituiçấo, o que năo implica dizer que o "petiano" náo teve autonomia para, sozinho, buscar atividades e eventos para aprofundar seus estudos, desde que apresentasse um relatório ao tutor.

Assim, com estudos de pós-doutoramento na temática das relaçóes raciais pudemos, assim, usar nosso conhecimento e nossa experiência para fortalecer a formaçăo dos "petianos" sob sua responsabilidade, dentro da temática das relaçôes raciais e suas interfaces com a educaçăo, cobrando, exigindo esforço no seu crescimento pessoal e profissional, porém compreendendo suas limitaçōes e estimulando-o a buscar superar suas dificuldades.

Como resultados gerais percebemos que contribuímos para o crescimento pessoal e profissional dos acadêmicos envolvidos no projeto, propiciando-lhes ferramentas teóricas, metodológicas, de pesquisa, de ensino e de aplicaçāo teórica, em um movimento constante de reflexăo-açăo-reflexâo. Tudo em benefício da educaçăo e da sociedade amapaense e brasileira.

12 Os encontros para avaliaçăo das atividades eram frequentes envolviam num círculo de conversas no qual era aberto para consideraçóes por parte dos bolsistas, a fim de manifestarem suas dificuldades ou eventuais descontentamentos com o rumo do projeto, ou mesmo para destacar suas contribuiçóes para a mudança na percepçáo da questâo racial no Amapá, seja em nível pessoal ou coletivo. 


\section{REFERÊNCIAS}

ALVES, N. (org.). Formaçáo de professores: pensar e fazer. Sáo Paulo: Cortez, 2005.

BRASIL. Lei no 10.639, de 9 de janeiro de 2003. Altera a Lei no 9.394, de 20 de dezembro de 1996, que estabelece as diretrizes e bases da educaçăo nacional, para incluir no currículo oficial da Rede de Ensino a obrigatoriedade da temática "História e Cultura Afro-Brasileira", e dá outras providências. Brasília, 2003. Disponível em: <http://www. planalto.gov.br/ccivil_03/LEIS/2003/L10.639.htm>. Acesso em: 01 set. 2018.

BENJAMIN, W. Magia e técnica, arte e política: ensaios sobre literatura e história da cultura. Traduçăo de Sergio Paulo Rouanet. 7. ed. Săo Paulo: Editora Brasiliense, 1994.

BOSI, E. Memória e sociedade: lembranças de velhos. Săo Paulo: Companhia das Letras, 1994.

BRUNER, J. A Cultura da Educaçáo. Porto Alegre: Artmed, 2001.

CANEN, A. Educaçăo multicultural, identidade nacional e pluralidade cultural: tensōes e implicaçôes curriculares. Cadernos de Pesquisa, n. 111, 2000, p. 135-150.

CAVALLEIRO, E. dos S. Do silêncio do lar ao silêncio escolar: racismo, preconceito e discriminaçấo na educaçấo infantil. 6. ed. Săo Paulo: Contexto, 2012.

CHIZOTTI, A. Pesquisa em Ciências Humanas e Sociais. 4. ed. Săo Paulo: Cortez, 2000.

DÁVILA, J. Diploma de brancura: Educando o Brasil. Sâo Paulo. Editora da UNESP, 2006. FANON, F. Pele negra, máscaras brancas. Trad. Renato Silveira. Salvador: Edufba, 2008. FOSTER, E. da L. S. Garimpando pistas para desmontar racismos e potencializar movimentos instituintes na escola. Curitiba: Appris, 2015.

GOMES, N. L. Alguns termos e Conceitos Presentes no Debate Sobre Relaçôes Raciais no Brasil: Uma Breve Discussáo. In: Educaçăo antirracista: caminhos abertos pela lei Federal n¹0.639/03. Brasília: Ministério da Educaçăo, Secretaria de Educaçăo Continuada, Alfabetizaçăo e Diversidade, 2005.

GOMES, N. L. (Org.). Práticas pedagógicas de trabalho com relaçóes étnico-raciais na escola na perspectiva da Lei 10.639/03. Brasília: MEC, SECADI, 2012.

GOMES, N. L. A mulher negra que vi de perto: o processo de construçáo da identidade racial de professoras negras. Belo Horizonte: Mazza Ediçōes, 1995.

HECKERT, A. Narrativas de Resistências: Educaçăo e Políticas. Tese (Doutorado) Faculdade de Educaçăo, Universidade Federal Fluminense (UFF), Niterói - Rio de Janeiro, 2004.

LINHARES, C. Projeto de Pesquisa. Experiências Instituintes em Escolas Públicas: Memórias e Projetos para Formaçăo de Professores, 2000.

LINHARES, C. Projeto de Pesquisa. Experiências Instituintes em Escolas Públicas: Memórias e Projetos para Formaçăo de Professores II, 2002.

LINHARES, C. F. Experiências Instituintes em escolas públicas e formaçáo docente. Projeto de Pesquisa - UFF, 2006. 
LINHARES, C. Tempo de recomeçar: movimentos instituintes na escola e na formaçăo docente. In: DALBEN, A. (Org.) Convergências e tensóes no campo da formaçăo e do trabalho docente. Belo Horizonte: Autêntica, 2010, p.801-818.

LÜDKE, M.; ANDRÉ, M. Pesquisa em educaçáo: abordagens qualitativas. Săo Paulo: EPU, 2013.

MATURANA, H. Emoçóes e Linguagem na Educaçăo e na Política. Belo Horizonte: Editora da UFMG, 1998.

MELUCCI, A. Por uma Sociologia Reflexiva: pesquisa qualitativa e cultura. Petrópolis: Vozes, 2005.

MINAYO, M. C. de S. O Desafio do Conhecimento: pesquisa qualitativa em saúde. 11. ed. Săo Paulo, HUCITEC, 2008.

MUNANGA, K. Rediscutindo a mestiçagem no Brasil: identidade Nacional versus identidade negra. 3. ed. Belo Horizonte: Autêntica, 2008.

SOUZA, N. S. Tornar-se negro: as vicissitudes da identidade do negro brasileiro em ascensâo social. Rio de Janeiro: Graal, 1983.

QUASE DEUSES. Direçâo: Joseph Sargent. Produçâo: Mike Drake e Julian Krainin, Produtora: HBO Films, EUA, 2004. 1 DVD.

TRIVIÑOS, A. Introduçáo à pesquisa em ciências sociais: a pesquisa qualitativa em educaçăo. Săo Paulo: Atlas, 2008.

\section{Agradecimentos}

Agradecimentos ao Programa de Educaçăo Tutorial (PET) do Ministério da Educaçăo (MEC) pelo apoio financeiro à pesquisa, ao ensino e a extensăo universitária na UNIFAP. 